\title{
The effect of shale mineral powder on the strength of asphalt concrete
}

\author{
Shuxrat Buriyev", Shoxrux Davranov, Yokub Kuchkarov, and Iroda Saydakberova \\ Tashkent State Transport University, Tashkent, Uzbekistan
}

\begin{abstract}
In the article, work has been done to obtain shale mineral powder based on local raw materials and develop technologies to improve the physical and mechanical performance and durability of asphalt concrete, thereby increasing the physico-mechanical performance and durability of asphalt concrete, the density of fine-grained hot dense asphalt mix with shale mineral powder. The water absorption index of the asphalt concrete mixture decreases, the strength increases, and the transport performance of the road improves.
\end{abstract}

\section{Introduction}

According to the current policy of Uzbekistan, the highway plays an important role in attracting investment and the development of imports, tourism and tourism. The safer, smoother, more comfortable, and flatter the road, the faster the traffic and the lower the transportation costs. As a result, the cost of the product will be lower; we can deliver passengers and cargo to the destination quickly and conveniently. At present, we need to increase the technical performance of roads and ensure the pavement's smoothness and durability [1-4].

Low production of binder used for fine-grained hot asphalt concrete, which is laid on many roads under construction in the country, leads to an increase in the cost of production because it is not produced in the required quantities. In addition, mineral powder that does not meet the normative document requirements is used in the manufacture of asphalt concrete mixes. Due to the fact that the addition of mineral powder does not increase the activity of the binder, the compressive strength and density of asphalt concrete pavement are lower than the norm, water absorption is higher than the norm, resulting in defects in the coating, which leads to a sharp reduction in service life $[5,6]$.

Due to the low quality and durability of the fine-grained hot-density asphalt concrete mixture, the roads we are building are becoming unusable before their service life. One of the main reasons for this is that mineral powder is often not added to the composition of fine-grained hot dense asphalt concrete used in the coating, and the added mineral powder does not meet the requirements [7,9].

The majority of public roads are paved, and there is a growing demand for the construction and reconstruction of asphalt pavements. In their scientific work, many

* Corresponding author: bshx0708@gmail.com 
researchers have focused on the mineral powder in the asphalt concrete mix as a filler, only a small part, to ensure the coating density $[1,2]$.

In such cases, the powder obtained by crushing cement and ordinary stones is added to the composition of fine-grained hot dense asphalt concrete produced in the Republic. These added materials fill the small porosity between large and small aggregates in the composition of the asphalt concrete mix but do not serve to increase the strength of the asphalt mix, increase the activity of the binder. GOST16557-2005 "Mineral powder for asphalt concrete and organomineral mixtures" T.U. As a result of the low production of mineral powders that meet the requirements of Table 1 of the normative document, in some cases not added at all, the service life of the asphalt concrete mixture laid on the pavement is reduced [10-17].

\section{Methods}

The composition of asphalt concrete in the laboratory work was carried out on developing technologies for obtaining shale mineral powder based on local raw materials and improving the physical and mechanical performance and durability of asphalt concrete.

\section{Results and Discussion}

One of the main differences in the preparation of fine-grained hot dense asphalt concrete and coarse-grained hot porous asphalt concrete mixes is mineral powder's composition to the composition of this dense asphalt concrete mix. In other words, mineral powders added to the asphalt concrete mix increase the density of the mixture, increase its water permeability, water resistance and binder activity, improve the viscosity of the mineral part of the mixture and increase the strength of the mixture [6,8].

Mineral powder added to the preparation of fine-grained hot dense asphalt concrete mix is obtained by crushing dolomite, shale rocks, dolomites GOST 16557-2005 "Mineral powder for asphalt-concrete and organomineral mixtures" T.U. It is determined that it meets the requirements of the normative document, i.e. $70 \%$ pass through a $0.71 \mathrm{~mm}$ sieve on the degree of grinding, the sample size of bitumen mixed with mineral powder is 2.5 , Porosity, moisture content of at least $35 \%$ is $1.0 \%$ [4].

According to the classification of mineral powders are divided into two types:

MP-1 - derived from activated and activated carbonate rocks and bituminous rocks;

MP-2 - non-carbonated, obtained from solid parodies formed as a result of production;

Laboratory tests of mineral powder from shale rocks in the Samarkand region were conducted following GOST 16557-2005 "Mineral powder for asphalt-concrete and organomineral mixtures" T.U. compared with the requirements of the normative document. The test results are presented in Table 1 below. 
Table 1. Test results

\begin{tabular}{|c|c|c|c|c|c|}
\hline \multirow{2}{*}{ № } & \multirow{2}{*}{ Indicator names } & \multirow{2}{*}{$\begin{array}{c}\text { Unit of } \\
\text { measurement }\end{array}$} & $\begin{array}{c}\text { Normative } \\
\text { value }\end{array}$ & $\begin{array}{c}\text { The average } \\
\text { value } \\
\text { obtained }\end{array}$ & $\begin{array}{c}\text { Compatibility } \\
\text { with MX }\end{array}$ \\
\cline { 4 - 6 } & & $\%$ & $0-1.0$ & 0.8 & - \\
\hline 1 & Natural moisture & & At least 100 & 99.6 & Suitable \\
\hline \multirow{2}{*}{2} & Grain content, mm & 0.315 & At least 90 & 91.7 & Suitable \\
\cline { 4 - 6 } & & 0.071 & At least 80 & 81.2 & Suitable \\
\hline 3 & Density & $\mathrm{g} / \mathrm{sm} 3$ & $\begin{array}{c}\text { not } \\
\text { standardized }\end{array}$ & 2.6 & - \\
\hline 4 & Porosity, at least & $\%$ & 30 & 28.9 & Suitable \\
\hline \multirow{2}{*}{5} & $\begin{array}{c}\text { Most of the bitumen } \\
\text { mixing sample with } \\
\text { mineral powder }\end{array}$ & & 1.8 & 1.6 & Suitable \\
\hline
\end{tabular}

Shale rock product MP-1 mineral powder meets the requirements of the normative document GOST16557-2005 "Mineral powder for asphalt concrete and organomineral mixtures" T.U [4].

Mineral powder from shale rocks is an activated mineral powder of MP-1 type. Mineral powder from shale rocks increases the binding activity in the asphalt concrete mix. Shale rocks can be found on the territory of the Samarkand region and Karasoy village of Sh. Rashidov district of Jizzakh region. The mineral powder obtained from shale rocks is obtained by crushing these shale rocks into powder. In terms of grain composition, the mineral powder obtained from shale rocks, which meets the requirements of Table 1 of the normative document GOST16557-2005, increases the average density of the mixture by filling the fine pores between the coarse-grained hot asphalt concrete mix coarse-grained aggregate and fine-grained aggregate sand. The mineral powder obtained from shale rocks improves the bonding of the mineral part with the bitumen in the composition due to the high binding of the surface to bitumen.

Mineral powders, which are added to the composition of fine-grained hot dense asphalt concrete, are obtained in the country today by crushing several types of stone materials, and in some cases, cements. Numerous scientific studies have studied the effect of high water absorption on the asphalt concrete mix and the coating's physical and mechanical properties [3]. According to the results of this research, due to the high cost of mineral powder and low production, the mineral powder is not added to the fine-grained hot asphalt concrete mix produced in the country today. asfaltobetonnye, polimerasfaltobetonnye, asfaltobeton, polimerasfaltobeton for automobile roads and airfields "T.U. As a result of exceeding the norm specified in the normative document, there are cracks and distortions in the coating. This leads to a sharp reduction in the service life of the coating.

The strength and long-term performance of roads depend on the mixture's physical and mechanical properties and the application of deposition technologies [10]. In the laboratory in Jizzakh and Samarkand regions. The mineral powder obtained from is added to the composition of fine-grained hot dense asphalt concrete of type B. GOST 12801-98 "Materials based on organic fertilizers for road and aerodrome construction" M.I. Physical and mechanical properties of samples were prepared following GOST 9128-2013 "Mixtures of asphalt concrete, polymer asphalt concrete, asphalt concrete, polymer asphalt concrete for automobile roads and airfields" T.U. Laboratory tests were performed.

The mineral powder added to the asphalt concrete mix fills the fine gaps between the coarse and fine aggregates and binds well with the binder bitumen to form a solid mixture. 
GOST 9128-2013 "Mixtures of asphalt concrete, polymer asphalt concrete, asphalt concrete, polymer asphalt concrete for automobile roads and airfields" T.U. Table 3The composition of the hot asphalt concrete mix of type B was determined in Table 2.

Table 2. Granular composition as required by the normative document

\begin{tabular}{|c|c|c|c|c|c|c|c|c|c|c|}
\hline \multirow{3}{*}{$\begin{array}{l}\text { Type B type I hot asphalt } \\
\text { concrete }\end{array}$} & \multicolumn{10}{|c|}{ Grain size, mm, smaller than: } \\
\hline & ते & $n$ & 으 & $n$ & $\ddot{n}$ & $\stackrel{\overbrace{}}{\stackrel{n}{\tau}}$ & $\stackrel{\substack{0 \\
0}}{0}$ & $\frac{n}{m}$ & $\stackrel{0}{0}$ & 홍 \\
\hline & $\frac{8}{\frac{8}{2}}$ & $\frac{8}{8}$ & $\frac{8}{\frac{8}{2}}$ & $\begin{array}{l}8 \\
\text { 1 } \\
\text { in }\end{array}$ & 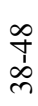 & $\begin{array}{l}\hat{m} \\
\hat{o} \\
\stackrel{1}{c}\end{array}$ & 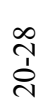 & 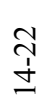 & $\begin{array}{l}0 \\
\dot{0}\end{array}$ & $\frac{1}{b}$ \\
\hline Bitumen content, $\%$ & \multicolumn{10}{|c|}{6.5} \\
\hline
\end{tabular}

In the laboratory GOST 12801-98 "Materials based on organic fertilizers for road and aerodrome construction" M.I., the effect of mineral powder in the development of type B fine-grained hot dense asphalt concrete mix was studied. Mineral powder with the addition of mineral powder from Azzikret material produced in the territory of Fergana region, mineral powder with the addition of mineral powder from limestone material in the territory of Tashkent region with the addition of mineral powder with the composition of shale rock Granular composition was selected according to Table 3 of the normative document GOST 9128-2013 "Mixture of asphalt concrete, polymer asphalt concrete, asphalt concrete, polymer asphalt concrete for automobile roads and airfields" (Table 3, 4, 5).

Table 3. Ingredients 1 Mineral powder obtained from Azzikret material produced in the territory of the Fergana region is added. $8.1 \%$ relative to total mass.

\begin{tabular}{|c|c|c|c|c|c|}
\hline $\begin{array}{c}\text { Sieve Size } \begin{array}{c}\text { Hfpvth cbnf } \\
(\mathrm{mm})\end{array} \\
\text { nnnyyy}\end{array}$ & $\begin{array}{c}\text { Weight of } \\
\text { Retained / } \\
\text { Ostatok na } \\
\text { site (g) }\end{array}$ & $\begin{array}{c}\text { Retained } \\
\text { Percentage / } \\
\text { Remaining on } \\
\text { site (\%) }\end{array}$ & $\begin{array}{c}\text { Passing } \\
\text { Percentage / } \\
\text { Proxod (\%) }\end{array}$ & \multicolumn{2}{|c|}{$\begin{array}{l}\text { Spec - Limit / } \\
\text { Normativy }\end{array}$} \\
\cline { 5 - 6 } & 12.0 & 1.9 & 98.1 & 100 & 90 \\
\hline 20.00 & 65.0 & 10.2 & 88.0 & 100 & 80 \\
\hline 15.00 & 92.0 & 14.4 & 73.6 & 100 & 70 \\
\hline 10.00 & 88.0 & 13.8 & 59.8 & 60 & 50 \\
\hline 5.00 & 96.0 & 15.0 & 44.8 & 48 & 38 \\
\hline 2.50 & 61.0 & 9.5 & 35.3 & 37 & 28 \\
\hline 1.25 & 53.0 & 8.3 & 27.0 & 28 & 20 \\
\hline 0.63 & 50.0 & 7.8 & 19.2 & 22 & 14 \\
\hline 0.315 & 37.0 & 5.8 & 13.4 & 16 & 10 \\
\hline 0.16 & 40.0 & 6.3 & 7.2 & 12 & 6 \\
\hline 0.071 & 46.0 & & & & \\
\hline Pan & & & &
\end{tabular}




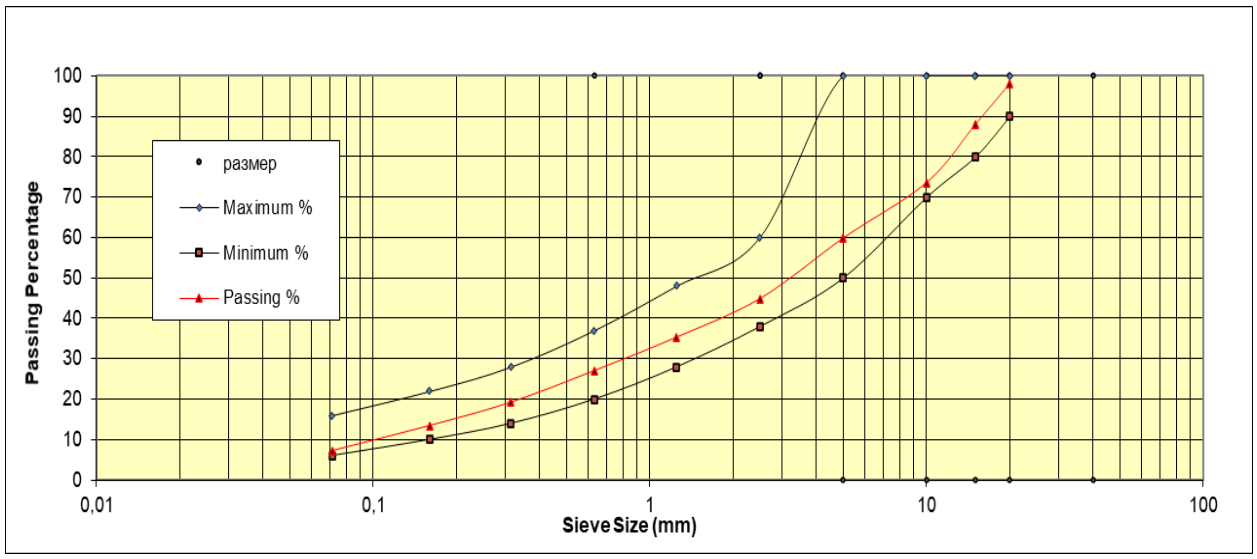

Fig. 1. Based on the data in Table 3, the analysis results are presented in the graph below.

Table 4. Ingredient 2 Mineral powder from limestone in Tashkent region is added. $7.8 \%$ relative to total mass.

\begin{tabular}{|c|c|c|c|c|c|}
\hline $\begin{array}{c}\text { Sieve Size } \mid \\
\text { Hfpvth cbnf } \\
(\mathrm{mm})\end{array}$ & $\begin{array}{c}\text { Weight of } \\
\text { Retained / } \\
\text { Ostatok na } \\
\text { site }(\mathrm{g})\end{array}$ & $\begin{array}{c}\text { Retained } \\
\text { Percentage / } \\
\text { Remaining on } \\
\text { site }(\%)\end{array}$ & $\begin{array}{c}\text { Passing } \\
\text { Percentage } \\
\text { / Proxod } \\
(\%)\end{array}$ & \multicolumn{2}{|c|}{$\begin{array}{c}\text { Spec - } \\
\text { Limit / } \\
\text { Normativy }\end{array}$} \\
\cline { 5 - 7 } & 0.0 & 0.0 & 100.0 & 100 & 90 \\
\hline 20.00 & 64.0 & 10.5 & 89.5 & 100 & 80 \\
\hline 15.00 & 88.0 & 14.4 & 75.0 & 100 & 70 \\
\hline 10.00 & 93.0 & 15.3 & 59.8 & 60 & 50 \\
\hline 5.00 & 89.0 & 14.6 & 45.2 & 48 & 38 \\
\hline 2.50 & 67.0 & 11.0 & 34.2 & 37 & 28 \\
\hline 1.25 & 42.0 & 6.9 & 27.3 & 28 & 20 \\
\hline 0.63 & 40.0 & 6.6 & 20.7 & 22 & 14 \\
\hline 0.32 & 45.0 & 7.4 & 13.3 & 16 & 10 \\
\hline 0.16 & 41.0 & 6.7 & 6.6 & 12 & 6 \\
\hline 0.07 & 40.0 & & & & \\
\hline Pan & & & & & \\
\hline
\end{tabular}

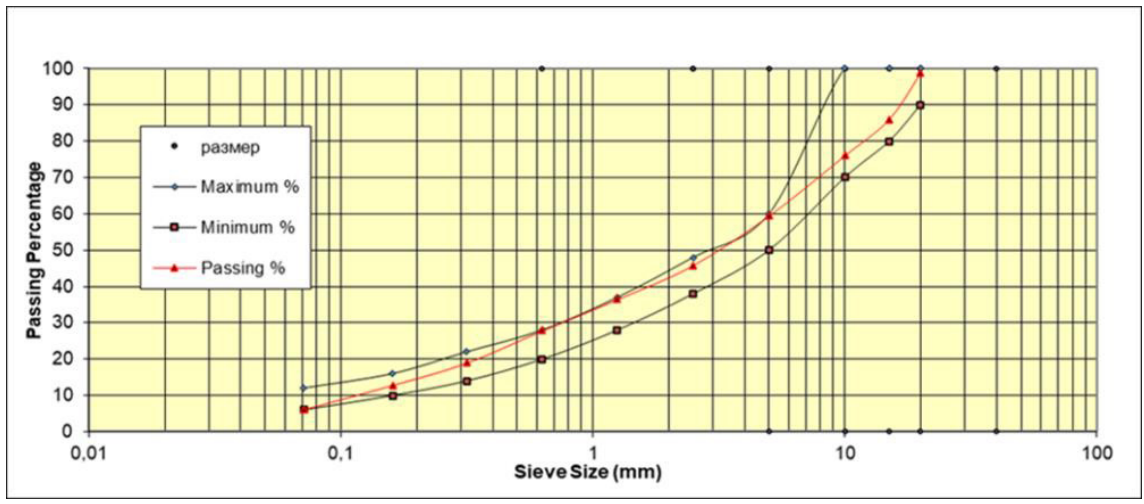

Fig. 2. Based on the data in Table 4, the analysis results are presented in the graph below. 
Table 5. Ingredient 3 Mineral powder is added from shale rock. $4.1 \%$ relative to total mass.

\begin{tabular}{|c|c|c|c|c|c|}
\hline \multirow{2}{*}{$\begin{array}{l}\text { Sieve Size } \\
\text { Hfpvth cbnf } \\
(\mathrm{mm})\end{array}$} & \multirow{2}{*}{$\begin{array}{l}\text { Weight of } \\
\text { Retained / } \\
\text { Ostatok na } \\
\text { site (g) }\end{array}$} & \multirow{2}{*}{$\begin{array}{c}\text { Retained } \\
\text { Percentage / } \\
\text { Remaining on } \\
\text { site }(\%)\end{array}$} & \multirow{2}{*}{$\begin{array}{l}\text { Passing } \\
\text { Percentage } \\
\text { / Proxod } \\
(\%)\end{array}$} & \multicolumn{2}{|c|}{$\begin{array}{c}\text { Spec - Limit / } \\
\text { Normativy }\end{array}$} \\
\hline & & & & Max & Min \\
\hline 20.00 & 18.0 & 1.9 & 98.1 & 100 & 90 \\
\hline 15.00 & 114.0 & 11.8 & 86.3 & 100 & 80 \\
\hline 10.00 & 119.0 & 12.3 & 74.0 & 100 & 70 \\
\hline 5.00 & 147.0 & 15.2 & 58.8 & 60 & 50 \\
\hline 2.50 & 129.0 & 13.3 & 45.5 & 48 & 38 \\
\hline 1.25 & 98.0 & 10.1 & 35.4 & 37 & 28 \\
\hline 0.63 & 87.0 & 9.0 & 26.4 & 28 & 20 \\
\hline 0.32 & 80.0 & 8.3 & 18.1 & 22 & 14 \\
\hline 0.16 & 63.0 & 6.5 & 11.6 & 16 & 10 \\
\hline 0.07 & 52.0 & 5.4 & 6.2 & 12 & 6 \\
\hline Pan & 61.0 & & & & \\
\hline
\end{tabular}

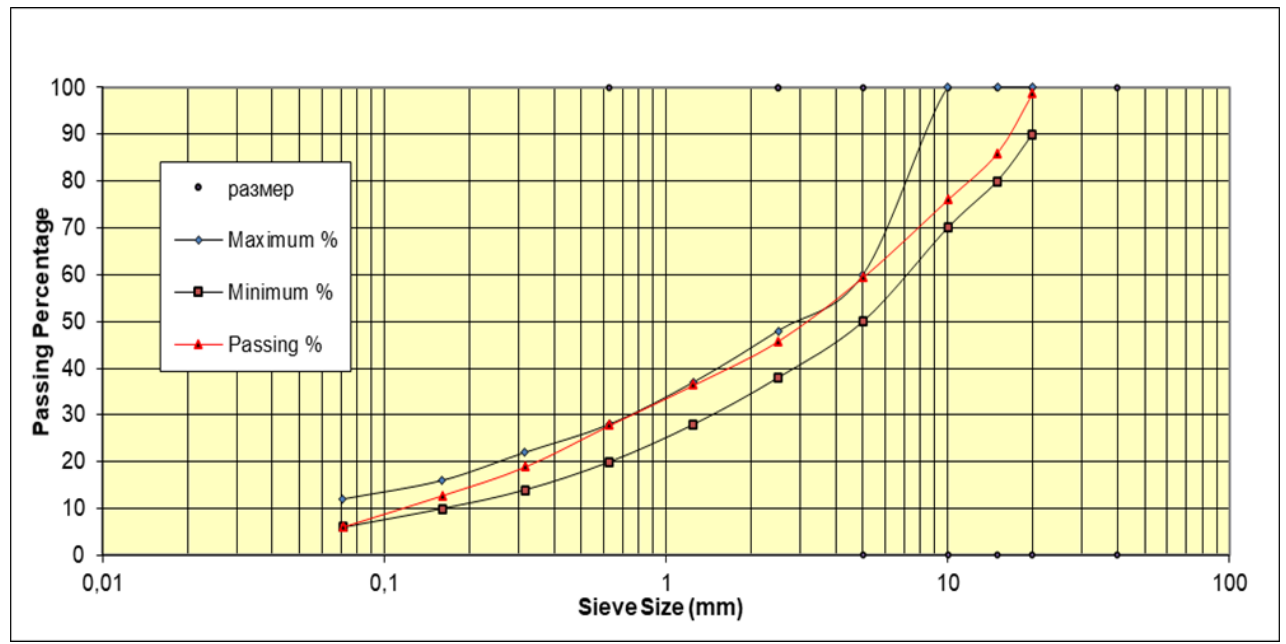

Fig. 3. Based on the data in Table 5, the results of the analysis are presented in the graph below

Physical and mechanical properties of fine-grained hot dense asphalt concrete mixes of type B with the addition of mineral powder from limestone material in Tashkent region and mineral powder from Azzikret material produced in Fergana region GOST 9128-2013 aerodromes" T.U. based on the requirements of the normative document, the mineral powder extracted from shale rock was compared with the test results (Table 6). 
Table 6. Mineral powder extracted from shale was compared with test results

\begin{tabular}{|c|c|c|c|c|c|c|}
\hline \multirow{3}{*}{ № } & \multirow{3}{*}{ Indicator names } & \multirow{3}{*}{$\begin{array}{c}\text { Unit of } \\
\text { measurement }\end{array}$} & \multicolumn{4}{|c|}{ The value of indicators } \\
\hline & & & \multirow{2}{*}{$\begin{array}{c}\text { Requirement } \\
\text { according to } \\
\text { GOST 9128-13 }\end{array}$} & \multicolumn{3}{|c|}{ The average value obtained } \\
\hline & & & & $\begin{array}{c}1 \\
\text { content }\end{array}$ & $\begin{array}{c}\text { Content } \\
2\end{array}$ & Content 3 \\
\hline 1 & $\begin{array}{l}\text { Compressive } \\
\text { strength } 20^{\circ} \mathrm{C}\end{array}$ & $\mathrm{MPa}$ & 2.5 & 2.78 & 2,575 & 3.14 \\
\hline 2 & $\begin{array}{l}\text { Compressive } \\
\text { strength } 50^{\circ} \mathrm{C}\end{array}$ & $\mathrm{MPa}$ & 1.1 & 1.25 & 0.96 & 1,239 \\
\hline 3 & $\begin{array}{l}\text { Compressive } \\
\text { strength } 60^{\circ} \mathrm{C}\end{array}$ & $\mathrm{MPa}$ & No demand & 0.96 & 0.92 & 0.97 \\
\hline 4 & $\begin{array}{l}\text { Compressive } \\
\text { strength } 70^{\circ} \mathrm{C}\end{array}$ & $\mathrm{MPa}$ & No demand & 0.71 & 0.738 & 0.85 \\
\hline 5 & $\begin{array}{l}\text { The amount of } \\
\text { binder }\end{array}$ & $\%$ & $5.0-6.5$ & 5.9 & 5.7 & 5.1 \\
\hline 6 & Average density & $\mathrm{g} / \mathrm{sm} 3$ & not standardized & 2.35 & 2.32 & 2.36 \\
\hline 7 & $\begin{array}{c}\text { Water } \\
\text { resistance, }\end{array}$ & & At least 0.85 & 0.92 & 0.84 & 0.98 \\
\hline 8 & $\begin{array}{c}\text { Water } \\
\text { absorption }\end{array}$ & $\%$ & $1.0-4.0$ & 4.0 & 4.8 & 3.1 \\
\hline
\end{tabular}

Ingredient 1 is a mineral powder derived from Azzikret material. 8.1\%

Ingredients 2 Mineral powder from limestone material is added.7.5\%

Ingredient 3 Mineral powder from shale rock is added. $4.1 \%$

The compaction strength of asphalt concrete used on highways can be seen in the following graph comparing the results obtained in the laboratory with 3 different composition and temperature changes.

\section{Compressive strength}

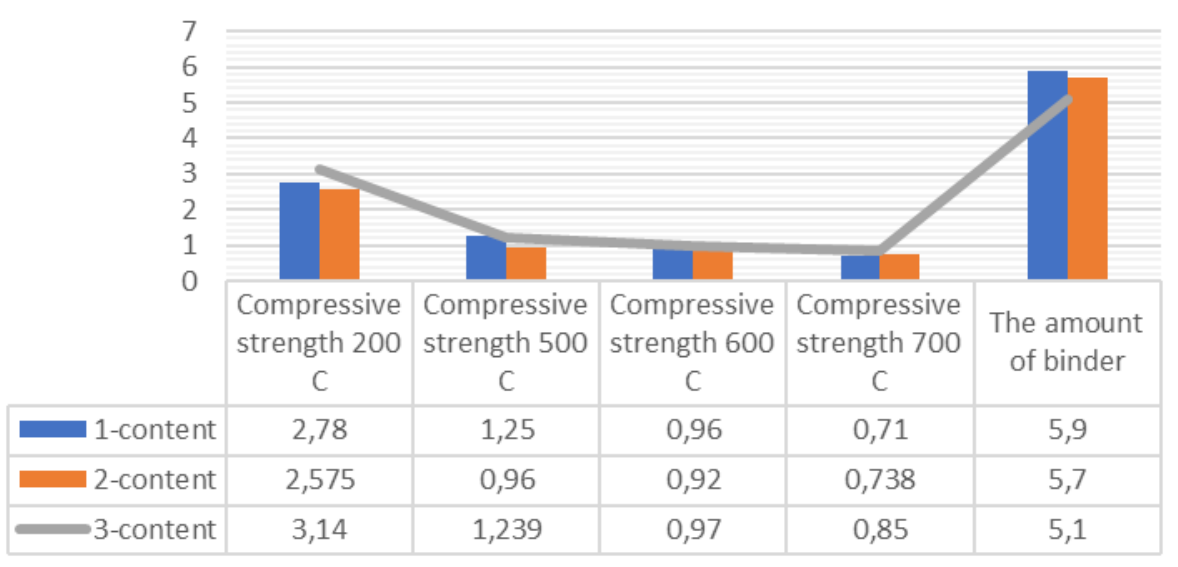

Fig. 4. Compressive strength of asphalt concrete used on highways.

Figure 4 is based on the data In Uzbekistan; during the summer months, when the air temperature is $45^{\circ} \mathrm{C}-50^{\circ} \mathrm{C}$, the temperature rises to $65^{\circ} \mathrm{C}-70^{\circ} \mathrm{C}$ in our asphalt pavements. GOST 9128-2013 "Mixtures of asphalt concrete, polymer asphalt concrete, asphalt concrete, polymer asphalt concrete for automobile roads and airfields" T.U. the normative document [5] contains the compressive strength requirements $0^{\circ} \mathrm{C}, 20^{\circ} \mathrm{C}$ and $50^{\circ} \mathrm{C}$. 
Therefore, we can see that the test results of type B fine-grained hot asphalt concrete mixture with mineral powder obtained from shale rocks at $60^{\circ} \mathrm{C}$ and $70^{\circ} \mathrm{C}$ at laboratory conditions are higher than the requirements given in the normative document at $50{ }^{0} \mathrm{C}$.

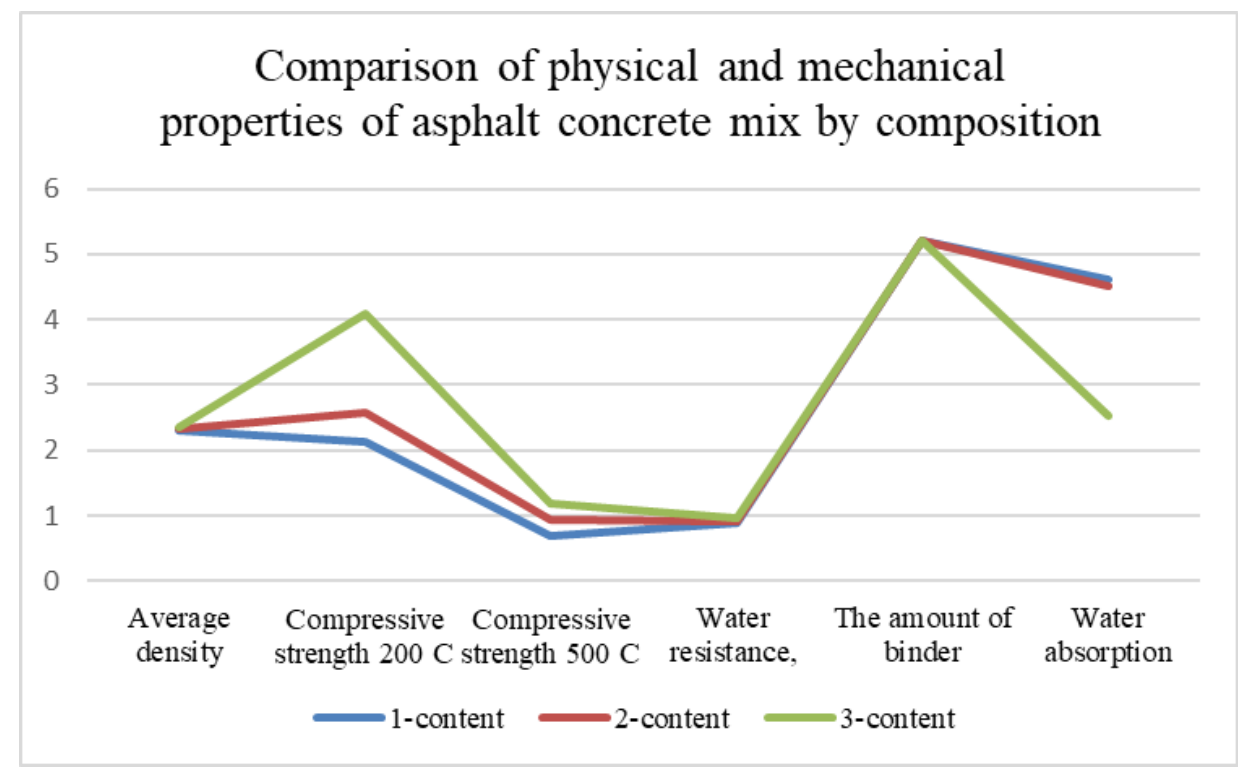

Fig. 5. 6 above based on the table, the physical and mechanical properties of the asphalt concrete mix were compared by composition.

As can be seen from the graph, the indicators of water resistance, water permeability, compressive strength and average density in terms of physical and mechanical properties mineral powder obtained from Azzikret material concentration Mineral powder made of limestone material we can see that the mineral powder obtained from the shale rocks is much higher than that of the fine-grained hot dense asphalt concrete samples.

\section{Conclusion}

The addition of mineral powder from shale rocks to the composition of fine-grained hot dense asphalt concrete increases the density of the mixture, the activity of the binder, and improves its viscosity relative to the mineral part of the mixture. Placed on the top layer of coating addition of mineral powder from shale rocks to the mix of fine-grained hot dense asphalt concrete increases water permeability, water resistance and strength of the mixture.

In Uzbekistan, in the summer months, when the air temperature is $45^{\circ} \mathrm{C}-50^{\circ} \mathrm{C}$, the temperature rises to $65^{\circ} \mathrm{C}-70^{\circ} \mathrm{C}$ in our asphalt pavements. GOST 9128-2013 "Mixtures of asphalt concrete, polymer asphalt concrete, asphalt concrete, polymer asphalt concrete for automobile roads and airfields" T.U. the normative document contains the compressive strength requirements $0^{\circ} \mathrm{C}, 20^{\circ} \mathrm{C}$ and $50^{\circ} \mathrm{C}$. Therefore, we can see that the test results of type $\mathrm{B}$ fine-grained hot asphalt concrete mixture with mineral powder obtained from shale rocks at $60^{\circ} \mathrm{C}$ and $70^{\circ} \mathrm{C}$ conditions in the laboratory are higher than the requirements given in the normative document at $50{ }^{\circ} \mathrm{C}$.

According to the results, when we add $4.1 \%$ of mineral powder from shale rocks, we get $0.8 \%$ of asphalt concrete mixture made of Azzikret material, $0.6 \%$ of mineral powder from limestone material, and $0.6 \%$ of viscous bitumen from asphalt concrete mixture. And we 
save half of the mineral powder. This leads to a reduction in the cost of the asphalt mix produced.

Asphalt concrete mix with mineral powder mixed from shale rocks was obtained by saving the amount of binder bitumen compared to the other two types of mineral powder mixed asphalt concrete mixes. Shale mineral powder has a great impact on asphalt concrete's physical and mechanical performance, leading to the longevity of asphalt concrete and the greening of road transport performance.

\section{References}

1. Dedyuxin Aleksandr Yurevich k. t.n., Associate Professor of Transport and Dorojnogo Stroitelstva UGLTU «Mineral powder as a means of stabilization and reinforcement of asphalt concrete mixes»

2. Tovboev B.X. and Umirzakov Z.A. «Effect of mineral powder on the physical and mechanical properties of asphalt concrete mixes»

3. V.D.Galdina, E.V.Gurova, O.I.Krivonos, M.S.Chernogorodova "Study of carbonmineral products of slate deposits in the quality of raw materials for the production of mineral components of asphalt concrete" "Construction and Architecture".

4. GOST 16557-2005 "Mineral powder for asphalt concrete and organomineral mixtures" Technical conditions, (2005)

5. GOST 9128-2013 "Mixture of asphalt concrete, polymerasphalt concrete, asphalt concrete, polymerasphalt concrete for automobile roads and airfields" Technical condition, (2013)

6. Morev A.A., Ilyasov V.N., Ilyasov S.V., Ilyasov V.S., Mrakin A.N., Selivanov A.A. Prospects for the use of shale and shale products and thermal processing in road construction. // International journal of applied and fundamental research, № 3-4, pp. 529-532, (2016)

7. Amirov T.J., Kochkarov B.N., Jamolov H.T. The effect of temperature of asphalt pavement on the accumulation of defects.

8. Radovskiy B.S. Problems of mechanical dorojno-stroitelnyx materials and dorojnyx odejd p. 240, (2003).

9. Gezentsvey L. B., Gorelyshev N. V., Boguslavskiy.A. M., Korolev I. V. Road asphalt concrete, M.Transport, p. 350, (1985)

10. Ladygina B.I. «Prochnost i dolgovechnost asfaltobetona». Minsk: Science and technology, (1987)

11. Rybakov V., Jos V., Raimova I., and Kudryavtsev K. Modal analysis of frameless arches made of thin-walled steel profiles. IOP Conf. Ser. Mater. Sci. Eng. 883, (2020).

12. Kattakulov F., Muslimov T., Khusainov A., Vokhidov O., Sultanov S. Water resource saving in irrigation networks through improving the efficiency of reinforced concrete coatings, IOP Conference Series: Materials Science and Engineering, 883(1), 012053, (2020)

13. Adilkhodjaev A., Hasanov B., Shaumarov S., Kondrashchenko V. Aerated concrete with predetermined pore parameters for the exterior walls of energy efficient buildings, IOP Conference Series: Materials Science and Engineering, 1030(1), 012006, (2021)

14. Khasanov B., Vatin N., Mirzaev T., Suyunov A., Radjabov M. Analysis of the mode of squeezing out excess water for mixing concrete mixture in the process of peristaltic compaction, IOP Conference Series: Materials Science and Engineering, 1030(1), 01202, (12021) 
15. Khasanov B., Vatin N., Mirzaev T., Suyunov A., Radjabov M. Physicochemical fundamentals of modifying concrete mix and concrete, IOP Conference Series: Materials Science and Engineering, 1030(1), 012022, (2021)

16. Khasanov B., Vatin N., Ismailova Z., Mirzaev T. Physical modification of concrete mix and concrete, IOP Conference Series: Materials Science and Engineering, 883(1), 012205, (2020)

17. Khasanov B., Irmuhamedova L., Firlina G., Mirzaev T. Theoretical foundations of the structure formation of cement stone and concrete, IOP Conference Series: Materials Science and Engineering, 869(3), 032032, (2020) 